TITLE:

\title{
ON THE GENUS SCYLLARUS (CRUSTACEA DECAPODA: REPTANTIA) FROM JAPAN
}

$\operatorname{AUTHOR}(\mathrm{S})$ :

Harada, Eiji

\section{CITATION:}

Harada, Eiji. ON THE GENUS SCYLLARUS (CRUSTACEA DECAPODA : REPTANTIA) FROM JAPAN. PUBLICATIONS OF THE SETO MARINE BIOLOGICAL LABORATORY 1962, 10(1): 109132

\section{ISSUE DATE:}

1962-07-30

URL:

http://hdl.handle.net/2433/175296

RIGHT: 


\title{
ON THE GENUS SCYLLARUS (CRUSTACEA DECAPODA : REPTANTIA) FROM JAPAN ${ }^{13}$
}

\author{
EIJI HARADA ${ }^{27}$
}

Seto Marine Biological Laboratory, Sirahama

With Plates VIII-XIV and 9 Text-figures

By putting the knowledge on the genus Scyllarus FABRIcius, listed by DE MAN (1916), and that gained thereafter together, we know at present 32 species belonging to this genus. They are :

The Atlanto-East-Pacific and the Mediterranean region:

Scyllarus arctus (LinNÉ)
S. americanus (S. J. SмITH)
S. depressus (S. I. Sмiтн)
S. paradoxus Miers
S. pygmaeus (SP. BATE)
S. crenulatus (Bouvier)
S. dol fini (Bouvier)
S. thiriouxi Bouvier
S. faxoni BouviER
S. chacei Holthuis
S. nearctus HolthuIs

The Indo-West-Pacific region :

Scyllarus rugosus H. Milne Edwards

S. bertholdi PAULSON

S. vitiensis (DANA)

S. $\quad$ sordidus (STIMPSON)

S. martensii PFefFer

S. batei Holthuis

S. rubens (AlCOCK and ANDERSON)

S. cultrifer (ORTMANN)

1) Contributions from the Seto Marine Biological Laboratory, No. 383.

2) Present address: Department of Zoology, University of Kyoto, Kitasirakawa, Sakyô-ku, Kyoto.

Publ, Seto Mar, Bịol, Lab., X (1), 1962, (Article 7) 


$\begin{array}{ll}\text { Scyllarus crenatus (WhITELEGGE) } \\ \text { S. } & \text { bicuspidatus (DE MAN) } \\ S . & \text { gibberosus (DE MAN) } \\ S . & \text { nobilii (DE MAN) } \\ S . & \text { paulsoni NoBILI } \\ S . & \text { pumilus NoBILI } \\ S . & \text { brevicornis HolthUIS } \\ S . & \text { mawsoni (BAGE) } \\ S . & \text { demani HolthUIS } \\ S . & \text { aesopius HolthUIS } \\ S . & \text { modestus HolthUIS } \\ S . & \text { ornatus HolthUIS } \\ S . & \text { timidus HolthUIS }\end{array}$

Of these species listed above, five species have so far been reported to occur in the Japanese waters, namely S. bicuspidatus (DE MAN), S. brevicornis HolthUIS, S. cultrifer (Ortmann), S. martensii Pfeffer, and S.rugosus H. Milne Edwards, though some of their identifications leave somewhat dubious points. All these five species have been collected only from the Pacific coasts of Japan.

The Japanese Scyllarus was first described by DE HAAN (1841) in the volume of "Crustacea" in Siebold's "Fauna Japonica." Although he had recognized two varieties in the Japanese Scyllarus, he only gave a short note for each form in comparison with his third variety of Scyllarus from China and provided a tiny drawing of the second variety (PI. 38, fig. 2). Owing to this, it is almost impossible to identify these varieties from his descriptions with certainty after we have known so much allied species occurring in the Japanese waters. Recently, Holthuis (1946) has published his extensive review of Decapoda Crustacea based on materials of the Snellius Expedition and others, in which he referred to those DE HAAN's varieties through detailed re-examination of them. According to HolthuIs, DE HAAN's three varieties fall into S. bicuspidatus, S. martensii and $S$. bertholdi respectively (p. 95, p. 96, p. 94). Consequently, I consider it proper to follow HolthuIs's views regarding DE HAAN's varieties in the present paper.

Quite recently, in March 1961, I happened to collect a specimen of Scyllarus by gill nets from rocky bottom, not deeper than 20 metres, near Mihonoseki on the Japan Sea coast of western Honshu. This is, as far as I know, the first record of Scyllarus from the Japan Sea. Besides, on closer examination it became clear that this specimen was not Scyllarus cultrifer inhabiting abundantly on the Pacific coasts of Kii Peninsula, but was identical to the form which I had recognized for a specimen caught by a fisherman from muddy bottom, not deeper than 30 metres, near Siraisi-sima amid the Seto Inland Sea while trawling. Moreover, on visiting the Misaki Park Aquarium, I witnessed that all Scyllarus being reared there were also identical to this form. In fact this form is a new one 
and is in many respects resembling to Scyllarus timidus HoLTHurs. Through reexamination of the collection of Scyllarus of the Seto Marine Biological Laboratory, I found a specimen of this form mixed up in a bottle with Scyllarus cultrifer from off Minabe $5 \mathrm{~km}$ north of the Laboratory. On the other hand, a specimen from Tanabe Bay, a specimen from Mihonoseki and all three specimens sent to me from the Amakusa Marine Biological Laboratory were identified as Scyllarus bicuspidatus. It is obvious, therefore, that these three species are by no means rare in the Japanese waters and have rather localized distributions.

Since the genus Scyllarus has been paid little attention and has left some confusion concerning the Japanese species, it may be appropriate to note on here four species (two of them are new) whose specimens are at my disposal and to refer to other species known to occur in the Japanese waters as well.

I wish to express my sincere thanks to Prof. H. UTinomi, Dr. T. Tokioka and Prof. D. Miyadi for giving their valuable advice and helpful criticism to the manuscript. I also wish to thank Dr. Isabella Gordon, of the British Museum (Natural History), Dr. J. Forest, of the Muséum National d'Histoire Naturelle, Dr. J. H. Sтоск, of the Amsterdam Zoologisch Museum, and Dr. L. B. Holthuis, of the Rijksmuseum van Natuurlijke Historie, for kindly allowing me to examine the specimens in their Museums. I am indebted to Dr. T. HABE, Mr. T. Yамамото and Mr. C. ArAga for many specimens afforded by them.

\section{Scyllarus bicuspidatus (DE MAN)}

(Japanese name: Hutaba-himesemiebi, nom. nov.)

(Text-figs. 1-2; Pl. X, figs. 7-9 ; Pl. XII, fig. 15 ; P1. XIII, fig. $19 ; \mathrm{Pl}$. XIV, fig. 21)

Scyllarus Arctus var. DE HAAN, 1841, Fauna Japonica, Crustacea, p. 154 (first variety).

Arctus bicuspidatus DE MAN, 1905, Tijdschr. Nederl. dierk. Ver., Ser. 2, Vol. 9, p. 589.

Scyllarus bicuspidatus DE MAN, 1916, Siboga-Exped., Monogr. $39 \mathrm{a}_{2}$, p. 80, P1. 2, figs. $12-12$ c.

Scyllarus bicuspidatus PARIsI, 1917, Atti Sco. Ital. Sci. nat., Vol. 56, p. 9.

Scyllarus bicuspidatus HoLthuis, 1946, Temminckia, Vol. 7, p. 95, Pl. 7, fig. e.

\section{Materials Examined.}

ㅇ (ovigerous) c.l.* $18.8 \mathrm{~mm}$, $q$ (ovigerous) c.l. $19.8 \mathrm{~mm}$ and $\circ$ (ovigerous) c.l. $22.4 \mathrm{~mm}$ from Nisi-no-umi, Amakusa. 17 March 1929. The collection of the Amakusa Mar. Biol. Lab.

o (ovigerous) c.l. $17.3 \mathrm{~mm}$ from Tanabe Bay. T. Yамамото coll. 20 May 1961.

3. c.l. $11.8 \mathrm{~mm}$ from Mihonoseki, Japan Sea. Collected by the people of Dept. Zool., Univ. Kyoto. 15 July 1961.

\footnotetext{
* c.l. means carapace length, namely the length from the level of the posterior margin of orbits
} along the median line down to the posterior border of the carapace, 
Description. The median and lateral carinae on the carapace, which are covered with larger distinct squamiform tubercles, are rather inconspicuous. The gastric region carries two sharp teeth in the middle line. The narrow marginal space behind the deep transverse groove near the posterior border of the carapace is

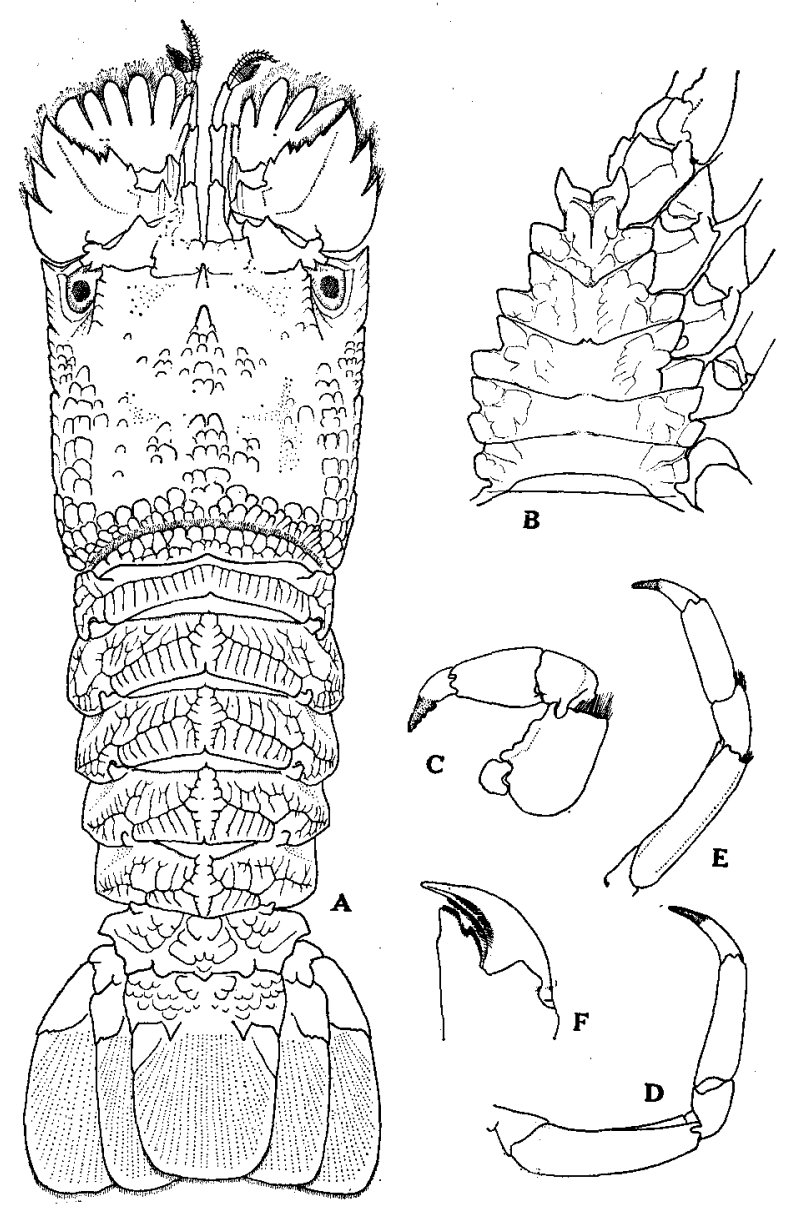

Text.fig. 1. Scyllarus bicuspidatus (DE MAN). A, dorsal view $(\times 1.7)$; B, thoracic sternum $(\times 2)$; , left first peraeopod $(\times 1.3)$; D, left second peraeopod $(\times 1.3)$; $E$, left third peraeopod $(\times 1.3) ; F$, subchela of left fifth peraeopod of female $(\times 7)$.

also furnished with distinct squamiform tubercles. The posterior border of the carapace is slightly and gently concave in the middle.

The abdominal median carina is hardly prominent. The reticular sculpturing on the posterior half of the first to fifth abdominal somites is distinct, leaving an arborescent areola in the median line on the second to fifth somites. The 
anterior half of the first abdominal somite is devoid of transverse furrows, and that of the second to fourth somites has a short transverse stria on each lateral half. The posterior margin of the first to fourth abdominal somites has a small median incision. The abdominal pleuron of the second to fourth somites is obtusely pointed and that of the fifth somite is round.

The antennular peduncle reaches to the distal end of the antenna. The
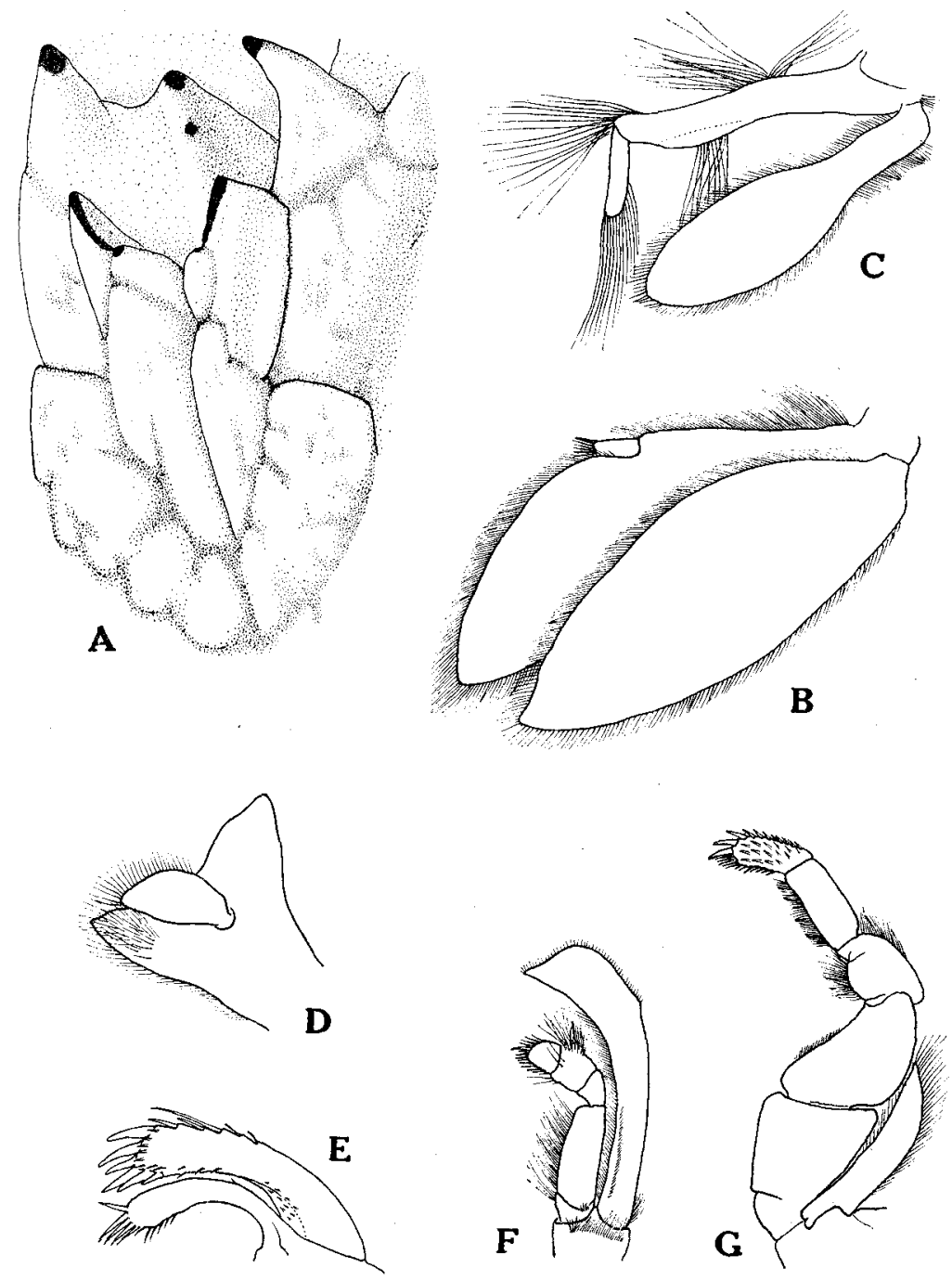

Text-fig. 2. Scyllarus bicuspidatus (DE MAN). A, anterior part of thoracic sternum in oblique view; $B$, left pleopod of second somite of female $(\times 4)$; C, left pleopod of third somite of female $(\times 4)$; D, left mandible $(\times 10) ; E$, left first maxilla $(\times 10) ; F$, left second maxilliped $(\times 4) ; \mathrm{G}$, left third maxilliped $(\times 4)$. 
anterior margin of the distal antennal segment carries five obtusely-pointed cusps, and its inner margin is armed with two teeth. The longitudinal carina on the dorsal surface of the second segment of the antenna is prominent, with faint transverse streaks over it. The anterior margin of this segment is armed with a strong tooth as well as four to five small teeth, and its outer margin carries two strong teeth and occasionally another small tooth. The anterior border of the antennular tergum is produced into three blunt projections generally.

The mandible has a 1-segmented palp which is fringed with rows of setose setae.

The edge of the ventral ridge of the merus of the first peraeopod is undulating, and that of the coxa is produced into a single sharp, brown-tipped process. The ventral side of the brown part of the dactylus of the first peraeopod is emarginate. None of the peraeopods are subchelate except the fifth of the female which forms a small subchela. The inner sides of the fingers of this subchela are covered with short hairs and denticulated. The dorsal sides of the propodus, carpus and merus of the third peraeopod have fringes of short hairs.

The anterior part of the thoracic sternum is bifurcate, with a median groove on it. Two processes of this part have brown-coloured edges on their inner sides, and the incision between them are truncate. The thoracic sternum is depressed gently in the middle. The postero-lateral angles of the thoracic sternum are not produced into spinous processes nor ridges in both sexes.

Remarks. This species has already been described and figured extensively be DE MAN (1916) and by HolthuIs (1946), to whose descriptions the present specimens accord quite well. Although DE MAN (1916, pp. 80-81) describes as "midway between the extremity of the gastric tooth and the faint cervical groove one observes two minute, sharp teeth, situated close abreast. Immediately behind the cervical groove are two similar acute teeth, situated also quite close to one another and a little larger than the anterior pair," these teeth appear to be, in my specimens, one of squamiform tubercles covering the median and lateral carinae of the carapace. The anterior bifurcate part of the thoracic sternum is comparatively longer in my specimens than in the figures given by DE MAN (1916, Pl. 2, fig. 12a) or by Holthuis (1946, Pl. 7, fig. e).

Distribution. This species has rather western range of distribution in the Japanese waters, but it occurs also on the western Japan Sea coasts of Honshu and on the southern coast of Kii Peninsula.

\section{Scyllarus cultrifer (ORTMANN) \\ (Japanese name: Himesemiebi)}

(Text-figs. 3-5 ; Pl. VIII, figs. 1-3 ; Pl. XII, fig. 13 ; Pl. XIII, fig. 17) 
Arctus sordidus BAte, 1888, "Challenger" Rept. Zool., Vol. 24, p. 66, Pl. 9, fig. 3.

Arctus haanii ORTMANN, 1891, Zool. Jharb. Syst., Vol. 6, p. 42.

Arctus cultrifer ORTMANN, 1897, Zool. Jahrb. Syst., Vol. 10, p. 272.

Scyllarus cultrifer BALss, 1914, Abh. Bayer. Akad. Wiss. Suppl. Vol. 2, Pt. 10, p. 80.

Scyllarus cultrifer DE MAN, 1916. Siboga-Exped., Monogr. $39 \mathrm{a}_{2}$, p. 68.

Scyllarus cultrifer PARISI, 1917, Atti Soc. Ital. Sci. nat., Vol. 56, p. 9.

Scyllarus sordidus BARNARd, 1926, Trans. Roy. Soc. S. Afr., Vol. 13, p. 122, Pl. 10.

Arctus cultrifer Yokoy A, 1933, Journ. Coll. Agric. Tokyo Imp. Univ., Vol. 12, p. 46.

Scyllarus cultrifer cultrifer HoLthuIs, 1960, Proc. Biol. Soc. Wash., Vol. 73, p. 150.

non Scyllarus cultrifer HolTHus, 1946, Temminckia, Vol. 7, p. 93.

Materials Examined.

ㅇ (ovigerous) c.l. $23.0 \mathrm{~mm}$, $\%$ (ovigerous) c.l. $17.3 \mathrm{~mm}$, o c.l. $16.4 \mathrm{~mm}$ and

ㅇ (ovigerous) c.l. $14.0 \mathrm{~mm}$ from off Minabè. 1938 (data unknown).

\}o c.l. $9.3 \mathrm{~mm}$ from Sisô-sima, Sirahama. E. Harada coll. August 1955.

of c.l. $10.1 \mathrm{~mm}$, के c.l. $18.1 \mathrm{~mm}$, क (ovigerous) c.l. $19.2 \mathrm{~mm}$ and + (ovigerous) c.l.

$20.3 \mathrm{~mm}$ from a tide pool, Tô-sima, Sirahama. H. Utinomi coll. 2 July 1956.

i c.l. $18.0 \mathrm{~mm}$ from Rinkai-ura, Sirahama.' T. Tsujı coll. 17 April 1958.

of c.l. $18.3 \mathrm{~mm}$ and + c.l. $16.5 \mathrm{~mm}$ from Sisô-sima, Sirahama. E. Harada coll. July 1958.

ô c.l. $5.5 \mathrm{~mm}$ from Seto, Sirahama. T. Үамамото coll. 13 February 1959.

ô c.l. $14.7 \mathrm{~mm}$, ô c.l. $15.8 \mathrm{~mm}$ and ơ c.1. $17.9 \mathrm{~mm}$ from Tô-sima, Sirahama. E. Harada coll. 30 April 1961.

of c.l. $9.0 \mathrm{~mm}$ and o c.l. $11.9 \mathrm{~mm}$ from Tanabe Bay. T. Үамамото coll. Мay 1961.

† (ovigerous) c.l. $23.0 \mathrm{~mm}$ from Tô-sima, Sirahama. T. INAGakI coll. 30 June 1961.

ô c.l. $11.0 \mathrm{~mm}$ from Tanabe Bay. T. Yamamoto coll. June 1961.

q c.l. $17.2 \mathrm{~mm}$ from Nada, Gobô. T. Yамамото coll. 29 August 1961.

Description. The carapace bears a low median carina and rather high lateral carinae. These carinae and the lateral margins of the carapace are covered with distinct squamiform tubercles. The gastric region carries two acute teeth on the median carina, the posterior one of which is stronger and is directing slightly upward. The lateral carina is armed with three acute teeth at the inner margin of and behind the orbit. The narrow space posterior to the transverse groove near the posterior border of the carapace is furnished with squamiform sculpturing. The posterior border of the carapace is sharply concave in the median line.

The abdominal longitudinal median carina is not emerginated almost at all. The reticular sculpturing on the posterior half of the first to fifth abdominal somites is conspicuous, with the arborescent areola in the median line on the second to fifth somites. The anterior part of the first to fourth abdominal somites has one or two distinct transverse furrows, of which those on the second to fourth somites are well developed, sometime interrupted in the median line 
and sometime ramified to connect each other. The abdominal pleuron of the second to fourth somites is rather sharply pointed. The anterior margin of the second abdominal pleuron is feebly serrated. The posterior border of the first to fourth abdominal somites has a median incision.

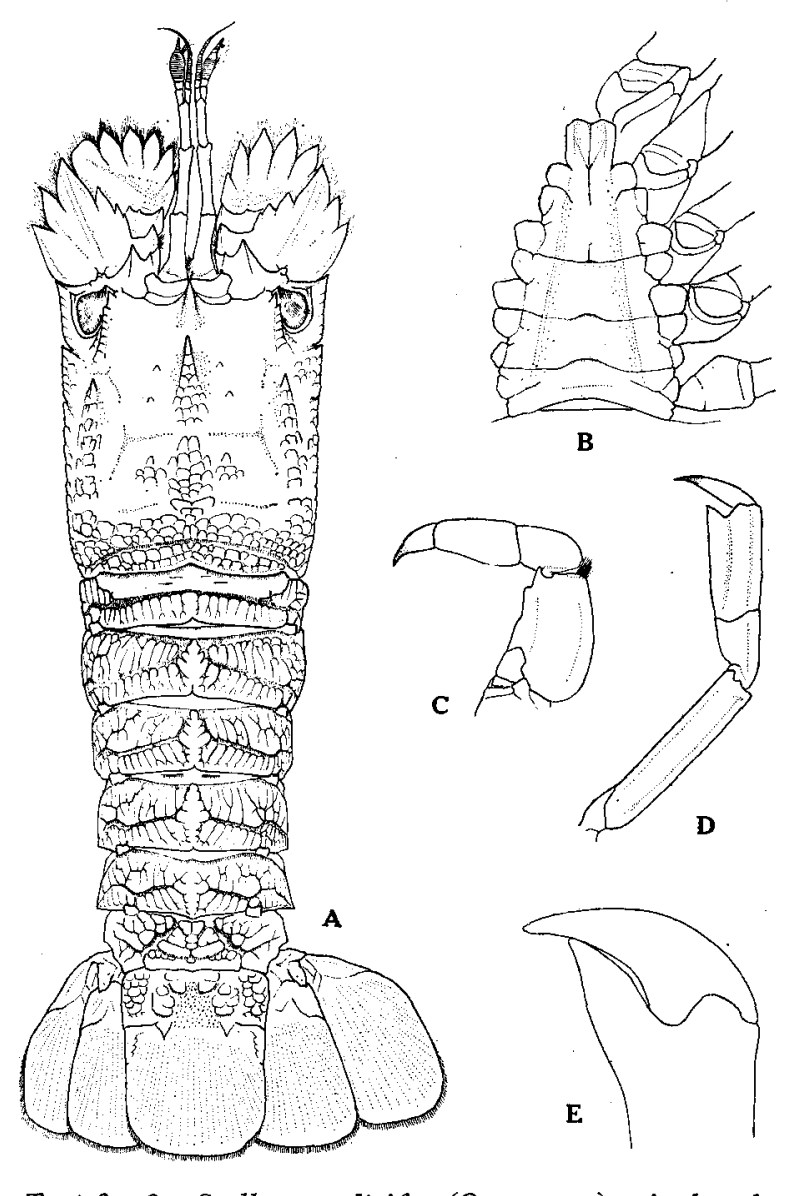

Text-fig. 3. Scyllarus cultrifer (ORTMANN). A, dorsal view $(\times 1.3) ; \mathrm{B}$, thoracic sternum $(\times 1.8)$; C, left first peraeopod $(\times 1.3)$; $D$, left third peraeopod $(\times 1.3)$; D, left third peraeopod $(\times 1.3)$; $\mathrm{E}$, subchela of left fifth peraeopod of female $(\times 7)$.

The antennular peduncle exceeds the second antenna by a half length of its third segment. The distal (fourth) segment of the antenna bears five cusps on its anterior margin and one tooth on its inner margin. These are all sharply pointed except the outermost one. The second segment of the antenna carries generally two sharp teeth, sometime with additional minute teeth, on its anteroinner margin and two sharp teeth on its outer margin. The longitudinal carina 

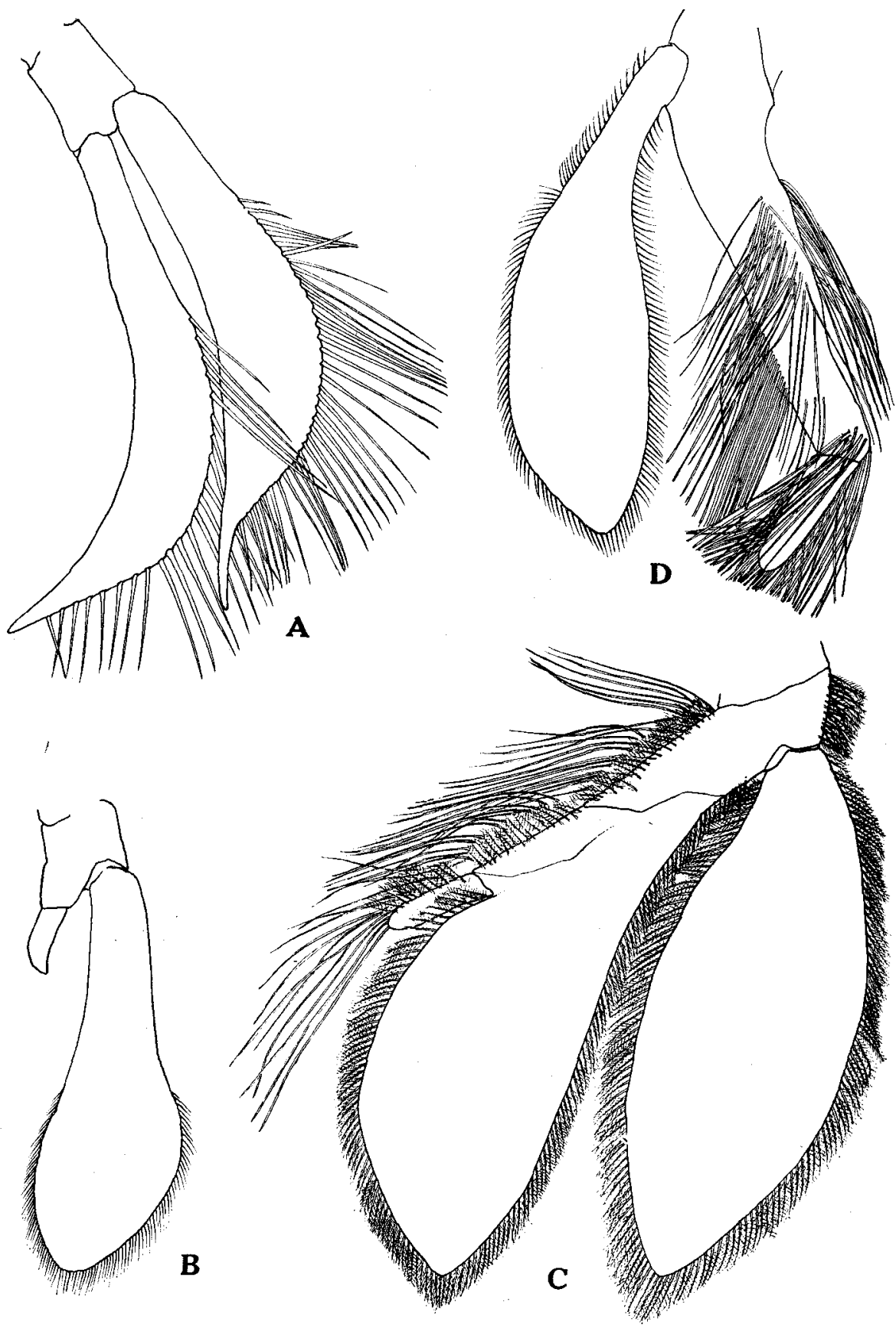

Text-fig. 4. Scyllarus cultrifer (ORTMANN). A, left pleopod of second somite of male $(\times 4)$; B, left pleopod of third somite of male $(\times 4)$; C, left pleopod of second somite of female $(\times 4) ; D$, left pleopod of third somite of female $(\times 4)$. 
on the dorsal surface of its segment is inconspicuous.

The mandible has a 1-segmented palp which is fringed with long setose setae.

The edges of the ventral ridges of the merus and coxa of the first peraeopod are almost straight. The propodi of the third and fourth peraeopods are somewhat flattened and broad dorso-ventrally and have spinous processes on the ventral sides of their distal ends, thus forming with the dactyli distinct subchelae. The propodus and carpus of the third peraeopod are furnished with rows of hairs on their dorsal sides. The fifth peraeopod forms a small subchela in female, the inner sides of fingers of which are smooth.

The thoracic sternum is depressed in the middle. The anterior part of it has a truncate appearance and is gutter-like furrowed. The postero-lateral angles of the thoracic sternum are not produced in spinous processes, but, in male, are raised into ridge-like elevations.

Remarks. This species was established by OrTmann (1897, p. 272) under the name of Arctus cultrifer. In his diagnoses ORTMANN remarks it as a distinct character for distinguishing this species that "Diese Art charakterisirt sich besonders durch die Propoden der dritten und vierten Pereiopoden: besonders am dritten Paar ist der Unterrand derselben messerartig zugeschärft und spring distal zahnartig vor, so das eine subchelate Bildung zu Stande kommt." This character has been repeatedly mentioned by various authors since BATE. BATE (1888, pp. 67-68) writes: "The third (peraeopod) differs from the second in having a thin flat marginal process extending from the carpal articulation to a sharp anteriorly-directed cusp or rudimentary pollex, and so forms with the dactylos imperfectly sub-chelate appendage." DE MAN (1896, p. 500) has rightly regarded that BATE's specimen should not be identical to Arctus sordidus of Stimpson (1860, p. 92) by this characteristic. Holthuis (1946, p. 93, Pl. 8, figs. c-e) gave the descriptions for his Scyllarus cultrifer once as follows: "The propodus of the third pereiopod, which is distinctly broader than those of the second and fourth, and sometimes subchelate (Pl. VIII, fig. e)," which was contradictory to the criterion originally used to distinguish Scyllatus cultrifer from others by Ortmann, and later on, Holthuis (1960, p. 150) himself established a new species, Scyllarus timidus, for this form by referring to those differences which he mentioned previously in 1946. In this paper (p. 150), Holthuis also established a new subspecies of Scyllarus cultifer meridionalis, to which he attributed the following characters that "the posterior part of the postrostral carina lacked squamiform sculpture but instead had a number of transverse hairy ridges; the posterior half of the first abdominal somite possessed more longitudinal grooves, every other pair of which was connected by transverse grooves; the fourth abdominal somite showed no median incision in the posterior margin; the anterior part of the sternum was wider than in S. cultrifer cultrifer and was not gutter-like depressed, showing only a median longitudinal groove." However, 
it is not clear from his descriptions whether this new subspecies has a subchelate third peraeopod and what kind of form the anterior part of the thoracic sternum of Scyllarus timidus has.

Now, through examination of specimens of Scyllarus at my disposal from the Japanese waters, these two characters, namely the gutter-like depression on the anterior part of the thoracic sternum and the subchelate third peraeopod, are proved to be in close correlation without fail. Carefull examination of BATE's figure (Pl. 9, fig. $3^{\prime \prime}$ ) of Arctus sordidus shows that his Challenger specimen has the

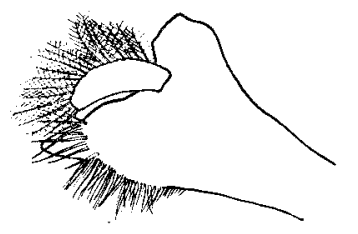

A
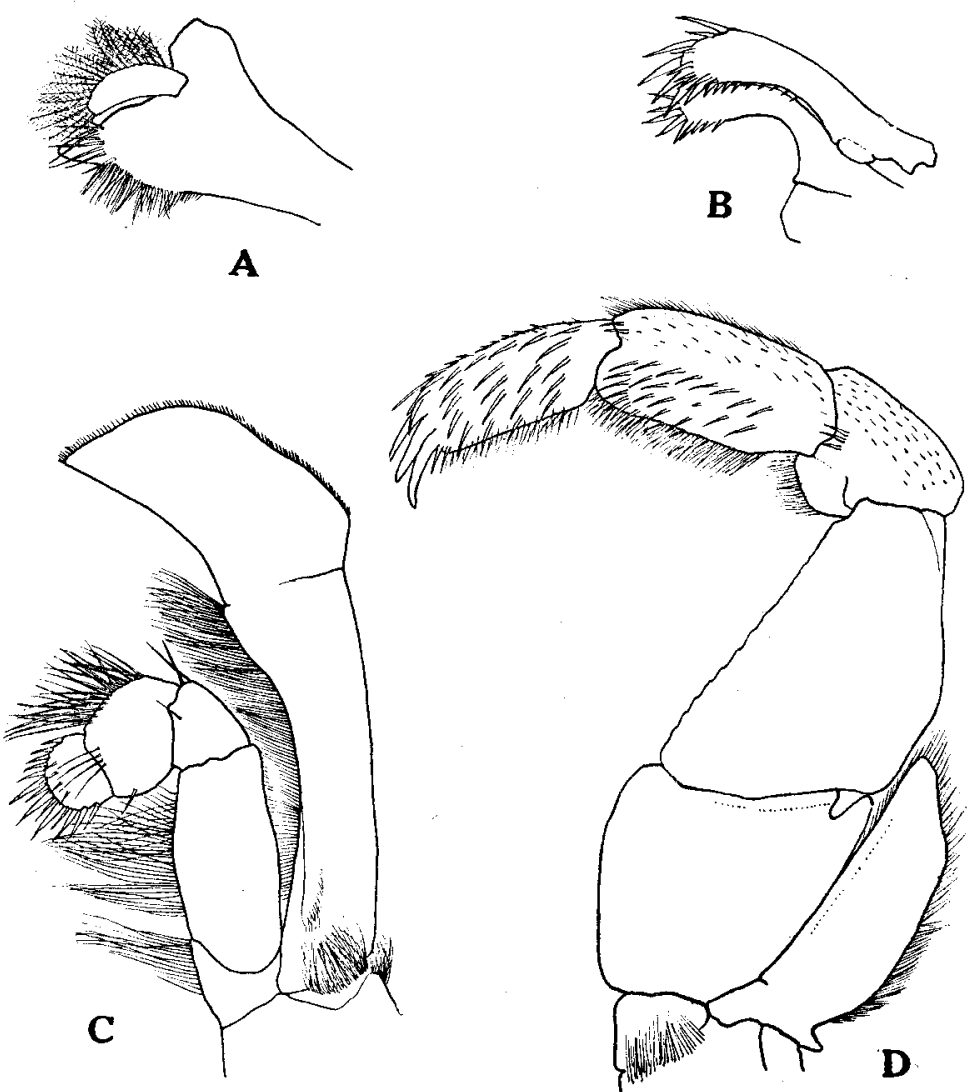

Text-fig. 5. Scyllarus cultrifer (ORTMANN). A, left mandible $(\times 10)$; $B$, left first maxilla $(\times 10) ; \mathrm{C}$, left second maxilliped $(\times 10) ; \mathrm{D}$, left third maxilliped $(\times 10)$.

subchelate third peraeopod and apparently, though only a left half of the thoracic sternum is drawn, that the anterior part of the thoracic sternum is gutter-like depressed as well. Moreover, the posterior part of the carapace behind the transverse groove has squamiform sculpturing in BATE's figure. It seems quite evident that BATE's specimen is Scyllarus cultrifer cultrifer and not Scyllarus cultrifer meridionalis as considered by Holthuss. 
Biology. This species is abundant in rocky areas on the southern coasts of Kii Peninsula. This is rather a shallow water inhabitant, though it has been collected from the bottom of more than 100 metres depth (Yokoya, 1933, p. 46). While diving I often observed the present animals lurking in small holes on rocks at various depths throughout a year, and occasionally crawling on pebbles and on sandy bottom in the vicinity of rocky reefs. It has also been collected from a tide-pool.

Ovigerous females were caught from May to August in the vicinity of the Seto Marine Biological Laboratory, however, the first stage phyllosoma larvae attributable to this species have been collected from April to August (Harada, unpublished data). Presumably the breeding season of this species is fairly long, extending from spring to summer.

Distribution. This species has southern range of distribution and occurs along the southern coasts of Japan. In Kii Strait, this species has been collected north up to Nada, Gobô, but none of Scyllarus caught at Saikasaki, Kitan Channel, were the present species.

Scyllarus kitanoviriosus, sp. nov.

(Japanese name: Kitan-himesemiebi, nom. nov.)

(Text-figs. 6-7 ; Pl. IX, figs. 4-6 ; Pl, XII, fig. 14 ; Pl. XIII, fig. 18)

\section{Materials Examined.}

o c.l. $21.5 \mathrm{~mm}$ from off Minabe. 1938 (date unknown).

i c.l. $22.9 \mathrm{~mm}$ from off Siraisi-sima, Seto Inland Sea. E. HARADA coll. 29 May 1958.

ô c.l. $23.7 \mathrm{~mm}$ from Mihonoseki, Japan Sea. E. Harada coll. 26 June 1961.

ô c.l. $18.6 \mathrm{~mm}$, o c.l. $23.2 \mathrm{~mm}$ and o c.l. $30.1 \mathrm{~mm}$ from Saikasaki, Kitan Channel. Spring 1961. The specimens kept in the Misaki Park Aquarium.

Description. The present species resembles in general features to Scyllarus cultrifer.

The median and lateral carinae on the carapace are not so much emerged, less prominent than in Scyllarus cultrifer. The squamiform tubercles covering these carinated parts, lateral margins and posterior part of the carapace are more distinct than in Scyllarus cultrifer. The gastric region carries two teeth. The anterior one just behind the rostral part is smaller and does not reach to the anterior margin of the antennular tergum, when it is seen from above, whereas in Scyllarus cultrifer it does. The posterior tooth is less elevated than in Scyllarus cultrifer and its terminal part is directing slightly upwards. The narrow marginal part behind the deep transverse groove near the posterior border of the carapace is furnished with two transverse furrows, from which longitudinal furrows are ramifying at places. The posterior border of the carapace has a 
sharp, small median incision.

The abdominal median carina is not distinctly elevated. The first to sixth abdominal tergites are separated into two portions each by a transverse groove. The anterior part of the first abdominal somite, which articulates with the
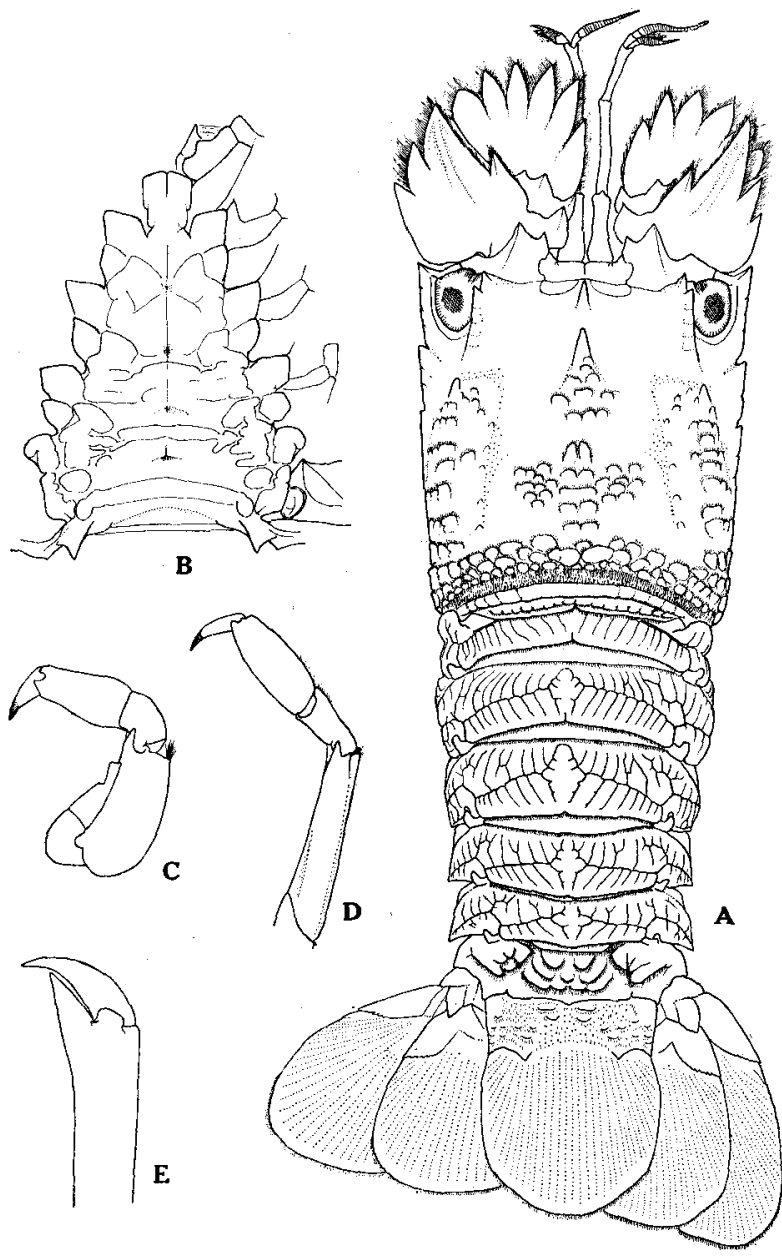

Text-fig. 6. Scyllarus kitanoviriosus, sp. nov. A, dorsal view $(\times 1.3)$; B, thoracic sternum $(\times 1.7) ; \mathrm{C}$, left first peraeopod $(\times 1.3) ; \mathrm{D}$, left third peraeopod $(\times 1.3)$; E, subchela of left fifth peraeopod of female $(\times 2.7)$.

carapace, has a pair of very short striae near its middle. The posterior part of this somite is furnished with distinct reticular sculpturing. On the anterior half of the second to fourth abdominal somites is a transverse stria which is interrupted into fragments. On the posterior half of the second to fifth abdominal 
somites is distinct reticular sculpturing, leaving an arborescent areola in the median line. The abdominal pleura of the second to fifth somites are ending in sharp spinous processes, and those processes of the second to fourth somites are directing obliquely backwards.

The antennular peduncle exceeds the antenna by one-third of the length of its third segment. The anterior margin of the distal antennal segment bears five cusps, and its inner margin bears a tooth and a faint trace of tooth. All teeth except the outermost one are sharply pointed. The second segment of the antenna bears two strong teeth on its outer margin, and a strong teeth on its inner margin. The longitudinal carinae on its dorsal surface are almost inconspicuous.

The 1-segmented mandibular palp is fringed with rows of short setae.

The first peraeopod has a straight ventral ridge on the merus and a emarginate ventral ridge on the coxa, the edge of the latter being brown-coloured at parts. The dactylus and propodus of the second peraeopod are not slender. The propodi of the third and fourth peraeopods are not flattened and are devoid of distal spinous processes, thus these two peraeopods do not form the subchelae. The fifth peraeopod is subchelate in female. The inner sides of its fingers are smooth. The third peraeopod has a row of marginal hairs on the dorsal sides of the propodus and carpus.

The anterior part of the thoracic sternum is truncate with a median groove on it. The postero-lateral angles of the thoracic sternum are produced into two spines situated abreast dorso-ventrally. The thoracic sternum is depressed a little in the median line.

Remarks. This species is a close relative to Scyllarus timidus Holthuis. As has been mentioned earlier in this paper, Scyllarus timidus was figured and noted in literature first by Holthuis (1946, p. 93, Pl. 8, figs. c-e) as Scyllarus cultrifer (ORTMANN) and was later separated from the latter as a new species by the same author (1960, p. 150). He does not give detailed descriptions for this new species. However, since he writes in the latter paper (1960, p. 151): "The name Scyllarus timidus is proposed here for the form described and figured by Holthuis (1946)," the characters given in his former paper $(1946$, p. 93 ) may be safely regarded as those of Scyllarus timidus, except the last one which is corrected in the latter paper (p. 151) by himself by saying that Scyllarus timidus may at once be distinguished from Scyllarus cultrifer "by lacking the sharp anteroventral tooth on the propodus of the third pereiopod." These characters generally retain good agreement for the present species, except the first and fourth ones which are not the case with the present species. In the present species the anterior margin of the second segment of the antenna bears only one strong tooth instead of two as in Scyllarus timidus, and the posterior tooth on the gastric region of the carapace is markedly less prominent than in Scyllarus timidus as drawn by 

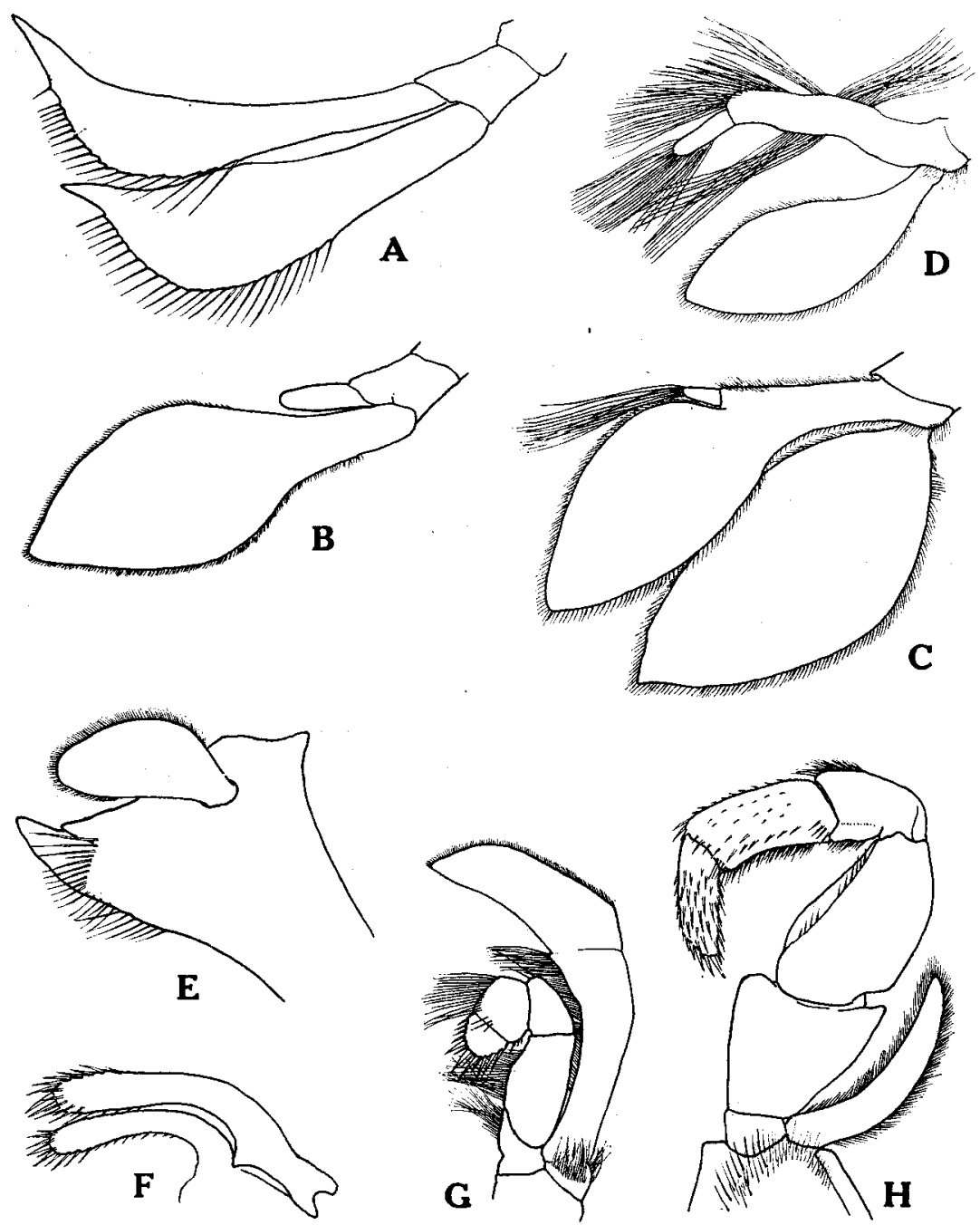

Text-fig. 7. Scyllarus kitanoviriosus, sp. nov. A, left pleopod of second somite of male $(\times 4)$; B, left pleopod of third somite of male $(\times 4)$; C, left pleopod of second somite of female $(\times 2)$; D, left pleopod of third somite of female $(\times 2) ; E$, left mandible $(\times 10) ; F$, left first maxilla $(\times 10)$; $\mathrm{G}$, left second maxilliped $(\times 4) ; H$, left third maxilliped $(\times 4)$.

Holthuis (1946, Pl. 8, fig. c). The sharply pointed abdominal pleura are seen in Scyllarus timidus, Scyllarus cultrifer and the present species as well.

Distribution. This species inhabits abundantly in the northern part of Kii Strait and occurs also in the Seto Inland Sea and in the Japan Sea; however, it has never been collected in the vicinity of the Seto Marine Biological Laboratory on the southern coast of Kii Peninsula, where Scyllarus cultrifer is very common. 
In contrast to Scyllarus cultrifer meridionalis, which HoLthuIs has distinguished as a southern form from the Japanese Scyllarus cultrifer cultrifer (1946, p. 150), the present species shows rather a northern range of distribution.

Holotype. A male specimen from Saikasaki, Kitan Channel, at the entrance of Osaka Bay, caught by fisherman's gill nets in spring of 1961 (date unknown) probably on rocky bottom, its measurements being $18.6 \mathrm{~mm}$ in carapace length, $97.0 \mathrm{~mm}$ in total body length (including antenna and telson) and $26.5 \mathrm{~mm}$ in carapace width (at its anterior end).

\section{Scyllarus longidactylus, sp. nov.}

(Japanese name: Tsumenaga-himesemiebi, nom. nov.)

(Text-figs. 8-9 ; Pl. XI, figs. 10-12 ; Pl. XII, fig. 16 ;

Pl. XIII, fig. 20; Pl. XIV, fig. 22)

Material Examined.

of c.l. $9.9 \mathrm{~mm}$ from Rinkai-ura, Sirahama. T. Yамамото coll. September 1958.

Description. The surface of the body is generally smooth.

The median carina on the carapace is prominent and the lateral carinae are fairly well emerged. These carinae are covered with distinct large squamiform tubercles. The gastric region carries two teeth, which are somewhat bluntly pointed. The anterior one, overhanging the rostral part, reaches to the half way of the length of the antennular tergum. The posterior one is hardly directing upwards. A pair of squamiform tubercles, situated abreast the median carina a little behind the posterior tooth in the gastric region, are turned to be obtuse teeth. Just behind the faint cervical groove are situated a bifurcate tooth in the median line and a pair of obtuse teeth abreast to it. The narrow marginal part of the carapace bears only a straight transverse furrow. The posterior margin of the carapace is gently concave in the median line.

The abdominal median carina is hardly raised at all. The first to sixth abdominal tergites consist of two portions separated by a transverse furrow. The anterior portions of these somites, which articulate with the preceeding somites, are smooth. The posterior portions of the first to fifth somites have distinct reticular sculpturing. The arborescent areola in the median line of the second to fifth somites is inconspicuous. The posterior margins of the first to fourth somites have deep median incisions. The first abdominal somite is marked with a median red spot.

The antennular peduncle extends a little beyond the anterior end of the antenna. The distal segment of the antenna bears four rounded cusps on its anterior margin, and a strong acute and a small tooth on the inner margin. The second segment of the antenna carries a prominent longitudinal carina on its dorsal 
surface. Both its outer and anterior margins have a strong acute tooth and a rudimentary tooth each. Two processes on the anterior margin of the first segment of the antenna are not projected into strong sharp spines.

The mandibular palp, 1-segmented, is fringed with rows of setose setae.

The ventral ridge on the merus and coxa of the first peraeopod is straight. The dactylus and propodus of the second peraeopod are slender and are of almost

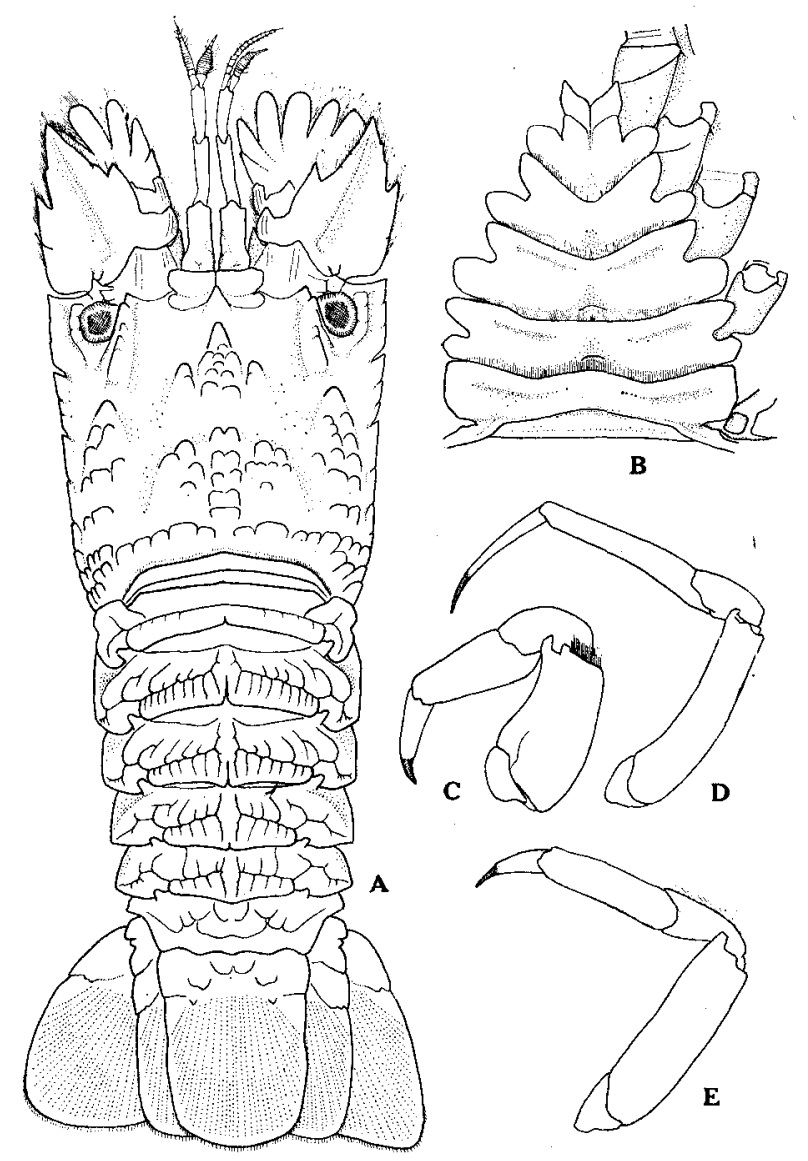

Text-fig. 8. Scyllarus longidactylus, sp. nov. A, dorsal view $(\times 2.5)$; $B$, thoracic sternum $(\times 2) ; C$, left first peraeopod $(\times 2.7)$; $D$, left second peraeopod $(\times 2.7)$; E, left third peraeopod $(\times 2.7)$.

equal length. The third and fourth peraeopod are not subchelate. The carpi of the third and fourth peraeopods and the meruses of the third to fifth peraeopods have ventral fringes of hairs.

The anterior part of the thoracic sternum is bifurcate. The anterior incision in this part is deep and not truncate. The third to fifth thoracic sternites bear 
pairs of transverse ridges on either side of the median depression. The posterolateral angles are not produced intó spinous processes nor ridges.

Remarks. Since the specimen treated here is a rather younger animal, these characters, specially the long, slender dactylus and propodus of the second peraeopod, need some discussions in connexion with relative growth. In his descriptions of Scyllarus martensii, DE MAN (1916, p. 88) writes: “The thoracic legs resemble closely those of Scyll. sordidus, but the propodi of the second legs are
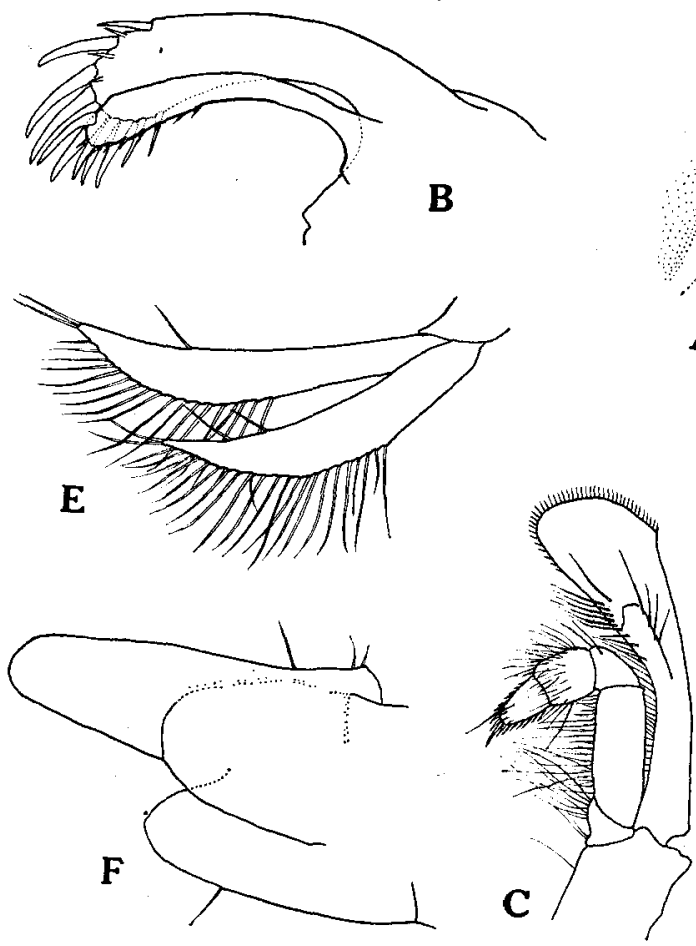

A
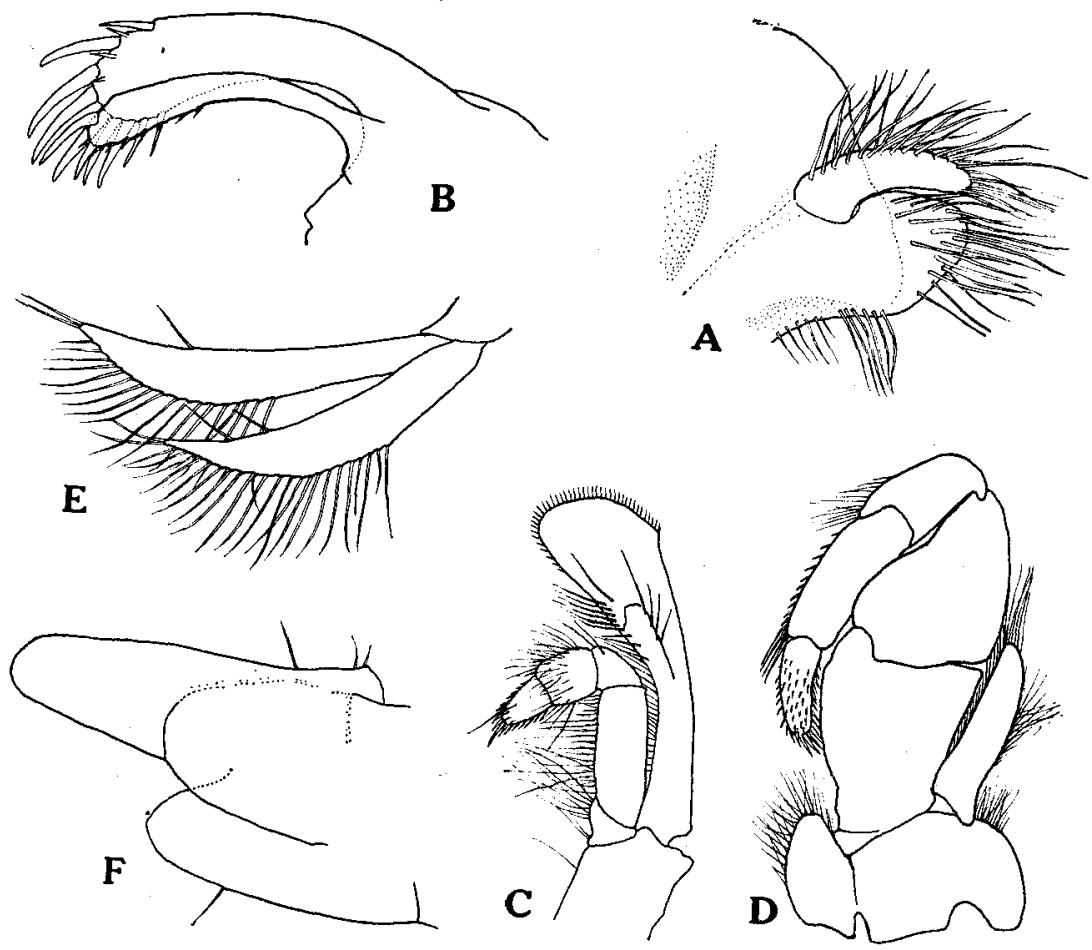

Text-fig. 9. Scyllarus longidactylus, sp. nov. A, right mandible $(\times 18)$; B, left first maxilla $(\times 18)$; $C$, left second maxilliped $(\times 10)$; $D$, left third maxil. liped $(\times 10) ; E$, left pleopod of second somite of male $(\times 4) ; F$, undeveloped left pleopod of third somite of male $(\times 10)$.

in STimpson's species a little slenderer...... In the younger, egg-bearing female from the same locality they are $2.14 \mathrm{~mm}$. long and $0.58 \mathrm{~mm}$. broad, appearing, in this younger individual, comparatively broader." Another phenomenon is known for Justitia longimana var. mauritiana and Panulirus ornatus by Gordon (1960, pp. $296,303,305,306$ ) that certain pairs of peraeopods undergo remarkable allometric growth. Although only a few facts are hitherto available concerning this kind of phenomena, there appear to be no cases where slender and long segments of legs become broad and short with growth. So the slender and long dactylus 
and propodus of the second peraeopod of the present species should be characteristic to this species and may not be due to the specimen being younger, in that this species differs from others. In Scyllarus gibberosus too, as described by DE MAN (1916, p. 92, Pl. 3, fig. 14c), the dactylus of the second peraeopod is long and slender, but not so much as in the present species.

In fact the present species is a close relative to Scyllarus vitiensis, and is in many respects resembling to Scyllarus gibberosus, Scyllarus martensii or Scyllarus modestus as well. The specimen of the present species is far larger than Scyllarus vitiensis, measuring $51.0 \mathrm{~mm}$ long from the tip of the antenna to the posterior end of the telson, while, as OrTmann (1897, p. 270) writes, Scyllarus vitiensis "scheint nicht gross zu werden: auch das Strassburger Exemplar ist klein, jedenfalls nicht grösser als das von DE MAN beschriebene $(29 \mathrm{~mm})$."* By comparing with the specimen of Scyllarus vitiensis in the Amsterdam Zoologisch Museum, the anterior part of the thoracic sternum of the present species is shown to differ from that of the former. In Scyllarus vitiensis the bifurcate ends are round, while in the present species they are rather sharp. The abdominal somites are hardly carinated in the middle line as in Scyllarus modestus, however the third abdominal somite is highest among them. The first to fourth abdominal tergites bear narrow incisions in the median line on their posterior margins as in Scyllarus gibberosus and Scyllarus vitiensis. Two teeth of the gastric region on the median carina are bluntly pointed, but there is not a trace of third tooth between these two, which is present in Scyllarus gibberosus. The squamiform tubercles on the surface of the carapace bears squamiform sculpturing behind the transverse groove near the posterior margin of the carapace, but the present species has a shallow transverse furrow instead. The distal end of the antennular peduncle does not reach to the anterior end of the antenna in Scyllarus gibberosus (DE MAN, 1916, Pl. 3, fig. 14), whereas it does in the present species. The terminal segment of the antenna of the present species has four rounded cusps on its anterior margin as in Scyllarus vitiensis, instead of five in Scyllarus gibberosus and Scyllarus martensii or seven in Scyllarus modestus. The second segment of the antenna carries a distinct ridge, unarmed with tubercles, on its dorsal surface, and bears a large acute tooth and an additional minute tooth on both the outer and anterior margin as in Scyllarus vitiensis, which is not the case with Scyllarus gibberosus or Scyllarus martensii.

Distribution. The only specimen at my disposal was collected on the shore in the vicinity of the Seto Marine Biological Laboratory.

Holotype. A male specimen from Rinkai-ura, Sirahama, its measurements being $9.9 \mathrm{~mm}$ in carapace length, $42.4 \mathrm{~mm}$ in total body length (including antenna and telson) and $13.2 \mathrm{~mm}$ in carapace width (at its anterior end).

* DE MAN's (1896) material is actually Scyllarus sordidus. 


\section{Scyllarus brevicornis HoLTHUis}

Arctus rugosus Yokoy A, 1933, Journ. Coll. Agric. Tokyo Imp. Univ., Vol. 12, p. 46, text-fig. 24. Scyllarus brevicornis HolthuIs, Temminckia, Vol. 7, p. 92.

Remarks. This species was first reported by Yokova (1933) from Bungo Strait, and since then no record of collection has been known.

\section{Scyllarus martensii PFEFFER}

Scyllarus Arctus var. DE HAAN, 1841, Fauna Japonica, Crustacea, p. 154, P1. 38, fig. 2 (second variety),

Scyllarus Martensii PFEFFer, 1881, Verh. naturw. Ver. Hamburg, Ser. 2, Vol. 5, p. 48.

Arctus martensii OrTmanN, 1891, Zool. Jahrb. Syst., Vol. 6, p. 48.

Scyllarus martensii Balss, 1914, Abh. Bayer. Akad. Wiss., Suppl. Vol. 2, Pt. 10, p. 79.

Scyllarus Martensii DE MAN, 1916, Siboga-Exped., Monogr. $39 \mathrm{a}_{2}$, p. 84, P1. 3, figs. 13-13 a.

Scyllarus martensii Holthuis, 1946, Temminckia, Vol. 7, p. 96.

Remarks. Records of collection hitherto known in Japan are from Sagami Bay and Kagosima Bay by Balss (1914) and from Kagosima by Ortmann (1891). This species seems to have a southern range of distribution.

\section{Scyllarus rugosus H. MILNE EDWARDS}

Scyllarus rugosus H. MiLNE EDWARDS, 1837, Hist. nat. Crust., Vol. 2, p. 283.

Arctus tuberculatus BATE, 1888, "Challenger" Rept. Zool., Vol. 24, p. 70, Pl. 10, figs. 1-2.

Arctus tuberculatus Doflein, 1900, S. B. Bayer Akad. Wiss., Vol. 30, p. 132.

Arctus tuberculatus LANCHESTER, 1901, Proc. Zool. Soc. London, 1901, Vol. 2, p. 557.

Scyllarus tuberculatus DE MAN, 1916, Siboga-Exped., Monogr. $39 \mathrm{a}_{2}$, pp. 68, 89.

Scyllarus rugosus HolthuIs, 1946, Temminckia, Vol. 7, p. 89, Pl. 7, fig. c, Pl. 8, fig. a, Pl. 9, fig. c. non Scyllarus tuberculatus DE MAN, 1924, Arch. Naturgesch., Vol. 90, Pt. 2, p. 53, text-fig. 18. non Arctus rugosus YoкоYA, 1933, Journ. Coll. Agric. Tokyo Imp. Univ., Vol. 12, p. 46, text-fig. 24.

Remarks. This species has been reported from the Japanese waters only once by Doflein (1900).

\section{Key to the Japanese Species of the Genus Scyllarus}

a. The abdominal somites II-V with the distinct median longitudinal carina.

Both the peraeopods III and IV not subchelate.

b. 3 distinct teeth on the outer margin of the 2 nd antennal segment. S. brevicornis HoLthuIs

bb. 4 distinct teeth on the outer margin of the 2nd antennal segment.

c. The abdominal somite I with its surface distinctly areolated by longitudinal striae and with a deep transverse groove. The gibbous, median carina on the abdominal somite III not nodulated. S. martensii PFEFFER 
cc. The abdominal somite I smooth, devoid of a deep transverse groove. The gibbous, median carina on the abdominal somite III produced into a large, tuberculated, laterally-compressed knob which is conspicuously overhanging posteriorly.

S. rugosus H. Milne Edwards

aa. The abdominal somites II-V without the distinct median longitudinal carina.

b. Both the peraeopods III and IV subchelate. The anterior part of the thoracic sternum truncate and with gutter-like furrow in the middle. S. cultrifer (ORTMANN)

bb. Both the peraeopods III and IV not subchelate.

c. The anterior part of the thoracic sternum rather truncate and with a longitudinal groove in the middle. S. kitanoviriosus, sp. nov.

cc. The anterior part of the thoracic sternum bifurcate.

d. 4 rounded cusps on the anterior margin of distal segment of the antenna. The dactylus and propodus of the 2 nd peraeopod slender and almost of equal length. S. longidactylus, sp. nov.

dd. 5 rounded cusps on the anterior margin of distal segment of the antenna. The dactylus far shorter than the propodus on the 2nd peraeopod. S. bicuspidatus (DE MAN)

\section{Sommario}

Sappiamo che pel Giappone sono state descritte fino ad oggi cinque specie appartenenti al genere Scyllarus, cionè: S. bicuspidatus (DE MAN), S. brevicornis Holthuis, S. cultrifer (OrTmanN), S. martensii Pfeffer e S. rugosus H. Milne EDwards. Da un accurato esame dei materiali nel Laboratorio biologico marino di Seto e dei miei materiali risulta che altre due specie nouve sono nella regione giapponese, cionè: S. kitanoviriosus, sp. nov. e S. longidactylus, sp. nov. Le loro descrizione, anche con le descrizione di due specie fuori da cinque specie, si danno in questa pubblicazione. Tre specie, S. bicuspidatus, S. cultrifer e S. kitanoviriosus, sono molto abbondanti. Anche nel Mar del Giappone in primo luogo sono state pescate le specie del genere Scyllarus, cionè: S. bicuspidatus e S. kitanoviriosus.

\section{REFERENCES}

BALsS, H. 1914. Ostasiatische Decapoden II. Die Natantia und Reptantia. Beiträge z. Naturgesch. Ostaciens, Abh. Bayer. Akad. Wiss., Suppl. Vol. 2, Pt. 10, pp. 1-101, text-figs. 1-50, PI. 1.

BATE, C. Spence. 1888. Report on the Crustacea Macrura collected by H.M.S. Challenger during the years 1873-76. "Challenger" Rept. Zool., Vol. 24, pp. i-xc+1-942, text-figs. 1-76, Pls. 1-150.

Doflein, F. 1900. Weitere Mitteilungen über dekapode Crustaceen der k. bayerischen Staatssammlungen. S. B. Bayer. Akad. Wiss., Vol. 30, pp. 125-145, figs. 1-3.

1902. Ostasiatische Dekapoden. Abh. Bayer. Akad. Wiss., Vol. 21, pp. 613-670, text-figs. A-D, Pls. 1-6. 
ForEST, J. and HolThuis, L. B. 1960. The occurrence of Scyllarus pygmaeus (Bate) in the Maditerranean. Crustaceana, Vol. 1, Pt. 2, pp. 156-163.

Gordon, Isabella. 1960. On the genus Justitia Holthuis (Decapoda, Palinuridae), with a note on allometric growth in Panulirus ornatus (Fabricius). Crustaceana, Vol. 1, Pt. 4, pp. 295-306.

HAAN, W. DE. 1833-50. Crustacea. In: P. F. DE Siebold's Fauna Japonica, pp. 1-244, Pls. 1-55+A-Q.

HolthuIs, L. B. 1946. Biological results of the Snellius Expedition. XIV. The Decapoda Macrura of the Snellius Expedition. I. The Stenopodidae, Nephropsidae, Scyllaridae and Palinuridae. Temminckia, Vol. 7, pp. 1-178, Pls. 1-11.

1960. Preliminary descriptions of one new genus, twelve new species and three new subspecies of Scyllarid lobsters (Crustacea Decapoda Macrura). Proc. Biol. Soc. Wash., Vol. 73, pp. 147-154.

LANChester, W. F. 1901. On the Crustacea collected during the "Skeat" Expedition to the Malay Peninsula, together with a note on the genus Actaeopsis. Proc. Zool. Soc. London, 1901, Vol. 2, pp. 534-574, Pls. 33-34.

MAN, J. G. DE. 1887. Bericht über die von Herrn Dr. J. Brock im indischen Archipel gesammelten Decapoden und Stomatopoden. Arch. f. Naturgesch., 1887, 53 Jahrg., Vol. 1, pp. 215-600, Pls. 7-22 a.

1896. Bericht über die von Herrn Schiffscapitän Storm zu Atjeh, an den westlichen Küsten von Malakka, Borneo und Celebes sowie in der Java-See gesammelten Decapoden und Stomatopoden. Zool. Jahrb., Abt. Syst., Vol. 9, No. 4, pp. 459-514.

1916. The Decapoda of the "Siboga" Expedition. Part III. Families Eryonidae, Palinuridae, Scyllaridae and Nephropsidae. Siboga-Expeditie, Monogr. $39 \mathrm{a}_{2}$, Leiden, 122 pp., 4 Pls.

1924. On a collection of macrurous decapod Crustacea, chiefly Penaeidae and Alpheidae from the Indian Archipelago. Arch. f. Naturgesch., 1924, 90 Jahrg., Abt. A, No. 2, pp. 1-60.

Milne-Edwads, H. 1837. Histoire Naturelle des Crustacés. Tome II. Paris, 532 pp.

ORtmanN, A. 1891. Die Decapoden-Krebse des Strassburger Museums, mit besonderer Berücksichtigung der von Herrn Dr. Döderlein by Japan Liu-Kiu-Inseln gesammelten und z. Z. im Strassburger Museum aufbewahrten Formen. III Theil. Die Abtheilungen der Reptantia Boas: Homaridea, Loricata und Thalassinidea. Zool. Jahrb., Abt. Syst., Vol. 6, No, 1, pp. 1-58.

1897. Carcinologische Studien. Ibid., Vol. 10, No. 3, pp. 258-372.

STIMPSON, W. 1860. Prodromus descriptionis animalium evertebratorum, quae in Expeditione ad Oceanum Pacificum Septentrionalem, a Republica Federata missa, Cadwaladaro Ringgold et Johanne Rodgers Ducibus, observavit et descripsit. Pars VIII. Crustacea Macrura. Proc. Acad. Nat. Sci. Philadelphia, Vol. 12, pp. 91-116.

YokOYA, Y. 1933. On the distribution of decapod crustaceans inhabiting the continental shelf around Japan, chiefly based upon the materials collected by s.s. Sôyô-maru, during the year 1923-1930. Journ. Coll. Agric. Tokyo Imp. Univ., Vol. 12, No. 1, pp. 1-226. 


\title{
EXPLANATION OF PLATES VIII-XIV
}

\author{
Plate VIII
}

Figs. 1-3. Scyllarus cultrifer (ORTMANN), a female specimen from Sirahama.

1. Dorsal view ; 2. Ventral view ; 3. Lateral view.

\section{Plate IX}

Figs. 4-6. Scyllarus kitanoviriosus, sp. nov., a male specimen from Saikasaki.

4. Dorsal view; 5. Ventral view; 6. Lateral view.

\section{Plate X}

Figs. 7-9. Scyllarus bicuspidatus (DE MAN), a female specimen from Amakusa.

7. Dorsal view ; 8. Ventral view; 9. Lateral view.

\section{Plate XI}

Figs. 10-12. Scyllarus longidactylus, sp. nov., a male specimen from Sirahama.

10. Dorsal view; 11. Ventral view; 12. Lateral view.

\section{Plate XII}

Figs. 13-16. Thoracic sternums.

13. Scyllarus cultrifer, a male specimen from Sirahama; 14. Scyllarus kitanoviriosus, a female specimen from Siraisisima; 15. Scyllarus bicuspidatus, a female specimen from Tanabe Bay; 16. Scyllarus longidactylus, a male specimen from Sirahama. 


\section{Plate XIII}

Figs. 17-20. Dorsal views of abdominal tergites.

17. Scyllarus cultrifer, a male specimen from Sirahama; 18. Scyllarus kitanoviriosus, a female specimen from Siraisisima; 19. Scyllarus bicuspidatus, a female specimen from Tanabe Bay; 20. Scyllarus longidactylus, a male specimen from Sirahama.

\section{Plate XIV}

Fig. 21. Oblique view of the anterior part of carapace of Scyllarus bicuspidatus.

Fig. 22. Peraeopods of Scyllarus longidactylus. 
Publ. Seto Mar. Biol. Lab., X, 1 (1962)
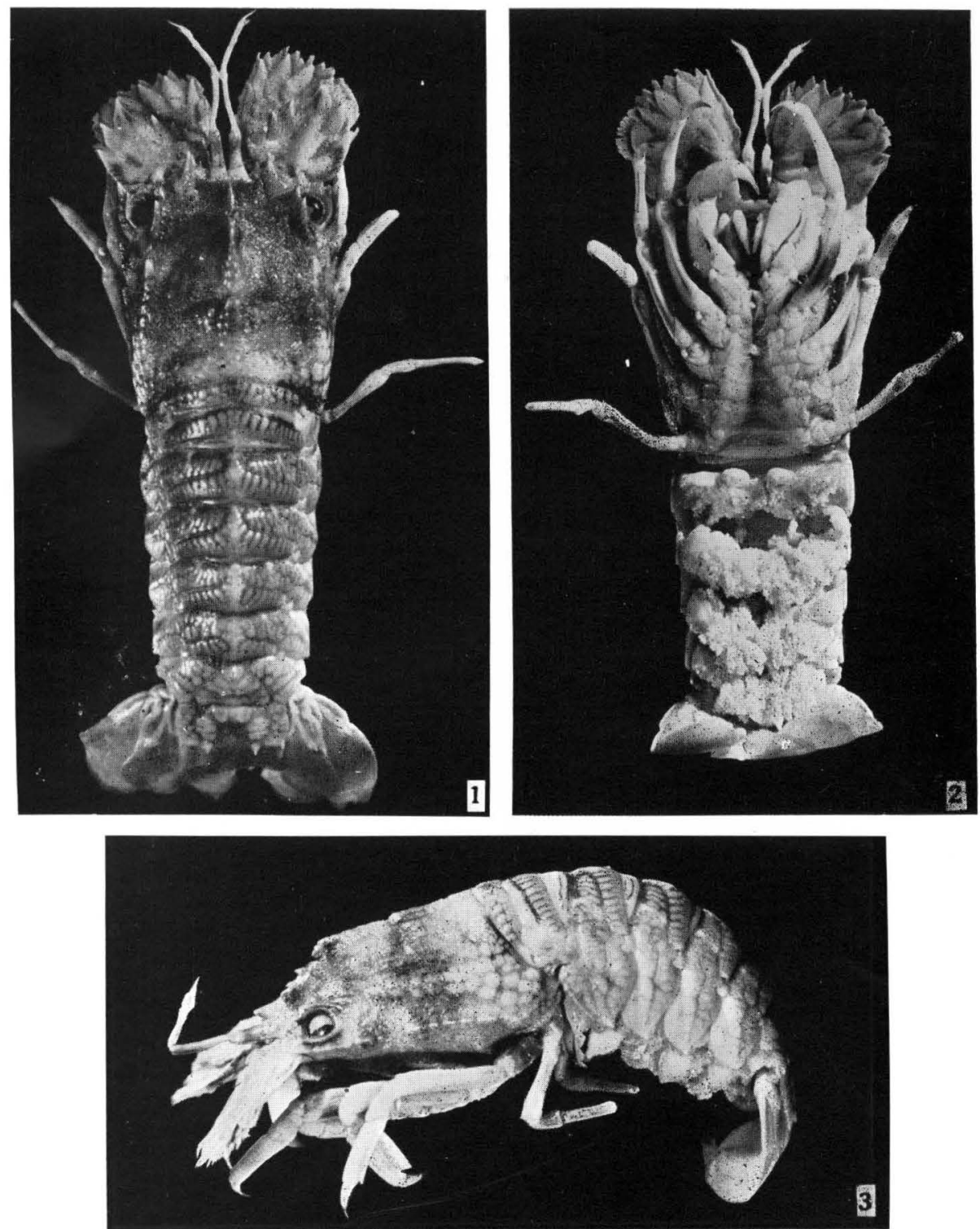

E. Harada: On the Genus Scyllarus from Japan. 
Publ. Seto Mar. Biol. Lab., X; 1 (1962)
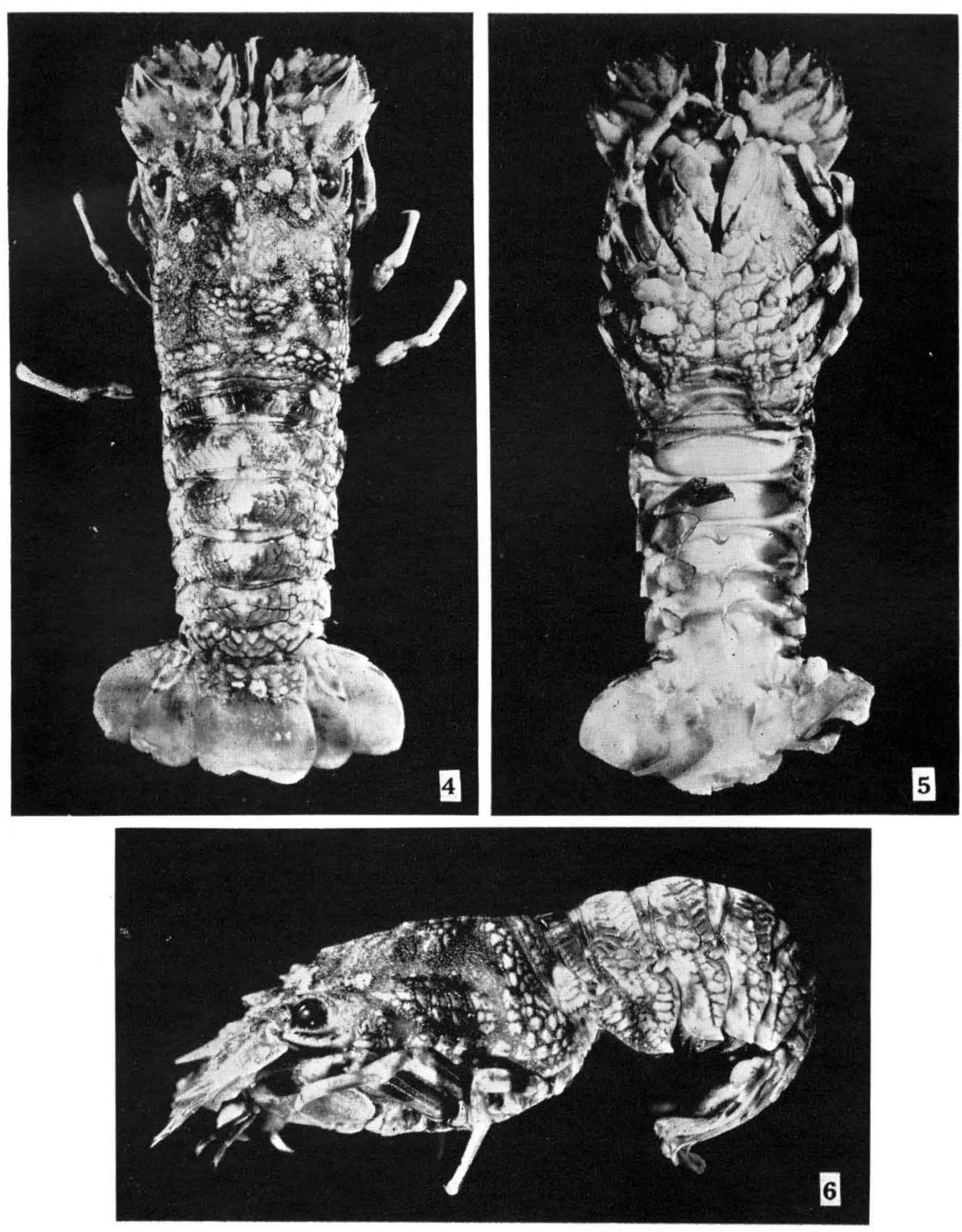

E. Harada: On the Genus Scyllarus from Japan. 
Publ. Seto Mar. Biol. Lab., X, 1 (1962)

PLATE X
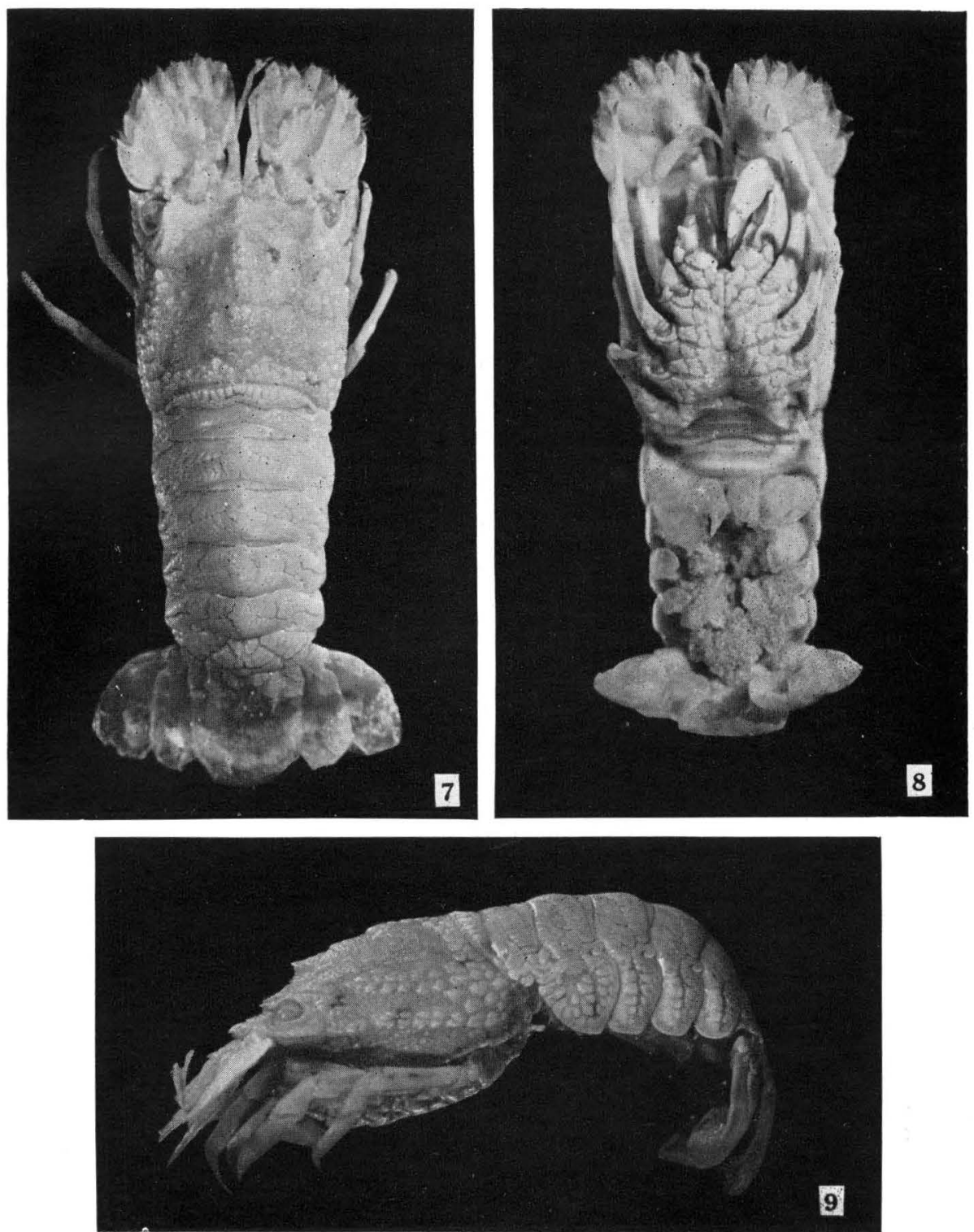

E. Harada: On the Genus Scyllarus from Japan. 
Publ. Seto Mar. Biol. Lab., X, 1 (1962)
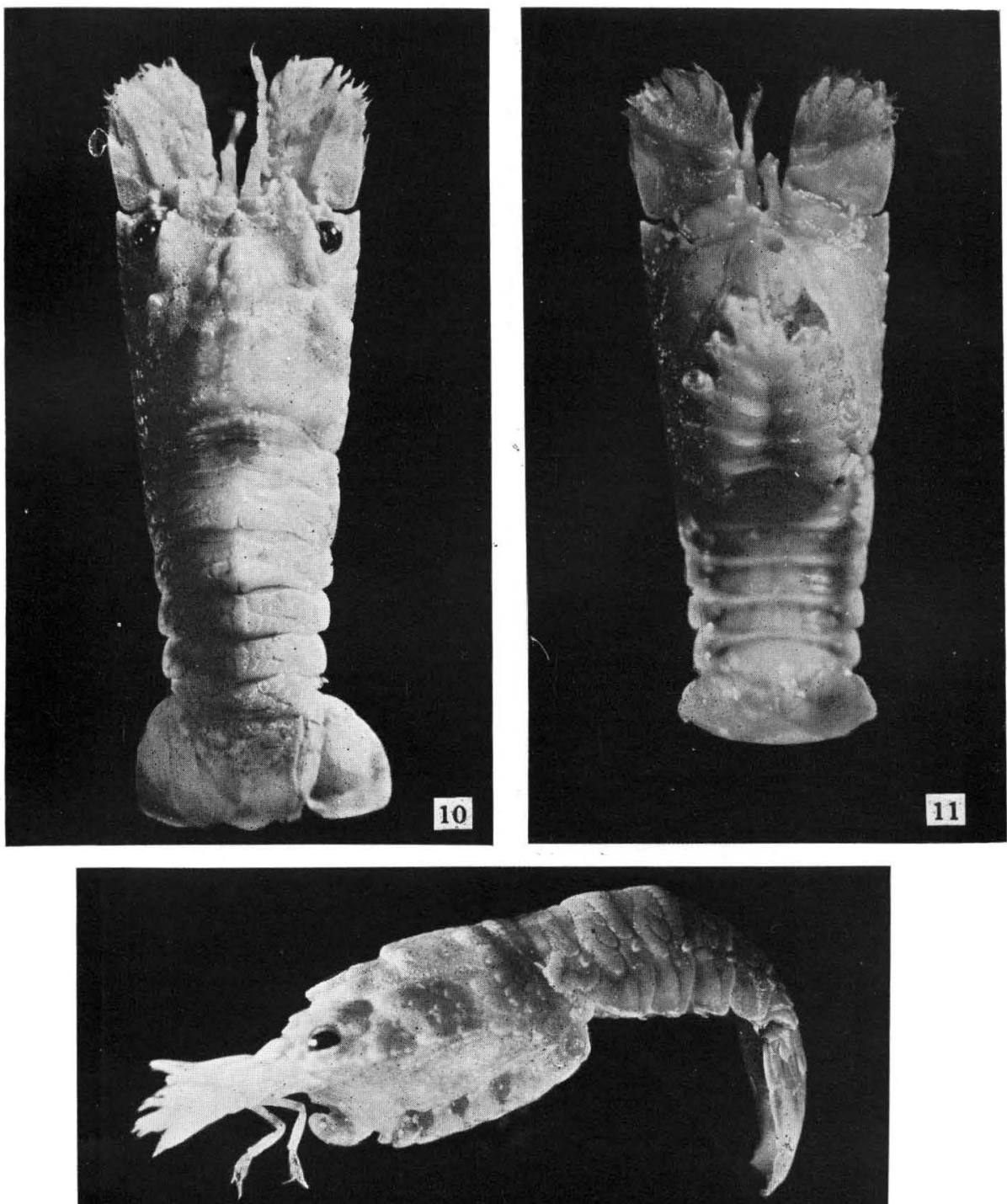

12

E. Harada: On the Genus Scyllarus from Japan. 
Publ. Seto Mar. Biol. Lab., X, 1 (1962)

PLATE XII
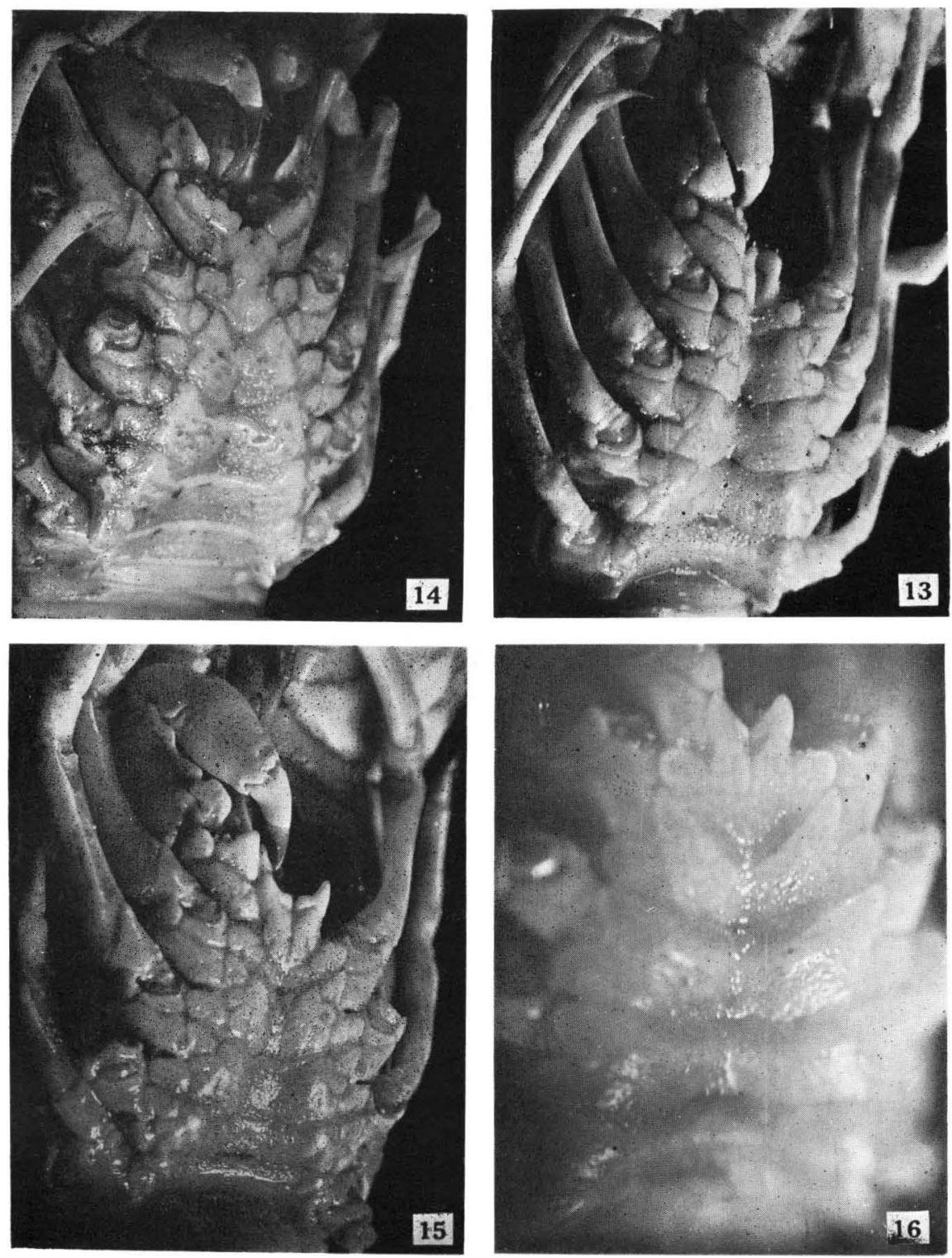

E. Harada: On the Genus Scyllarus from Japan. 
Publ. Seto Mar. Biol. Lab., X, 1 (1962) PLATE XIII
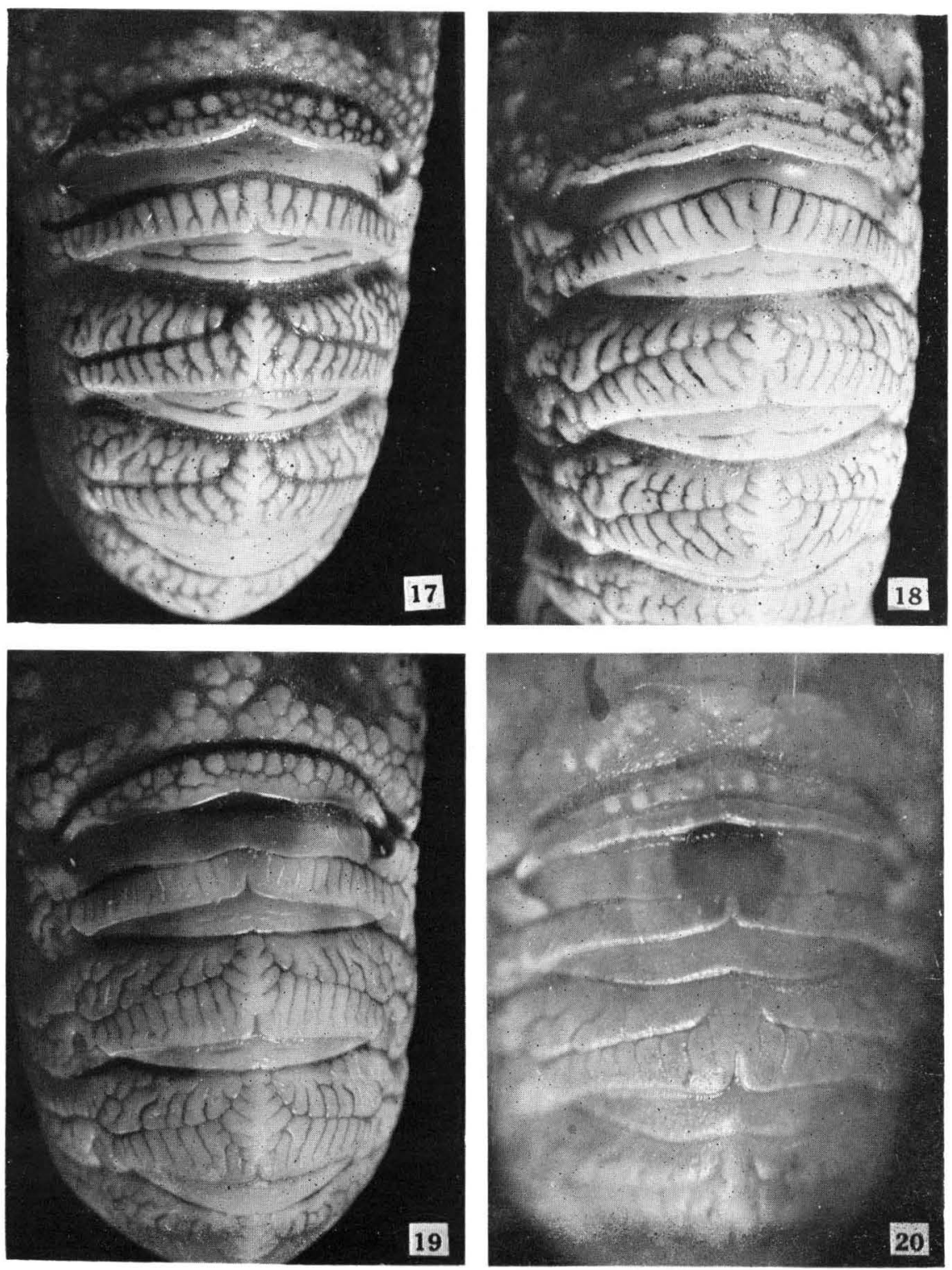

E. Harada: On the Genus Scyllarus from Japan. 
Publ. Seto Mar. Biol. Lab., X, 1 (1962)
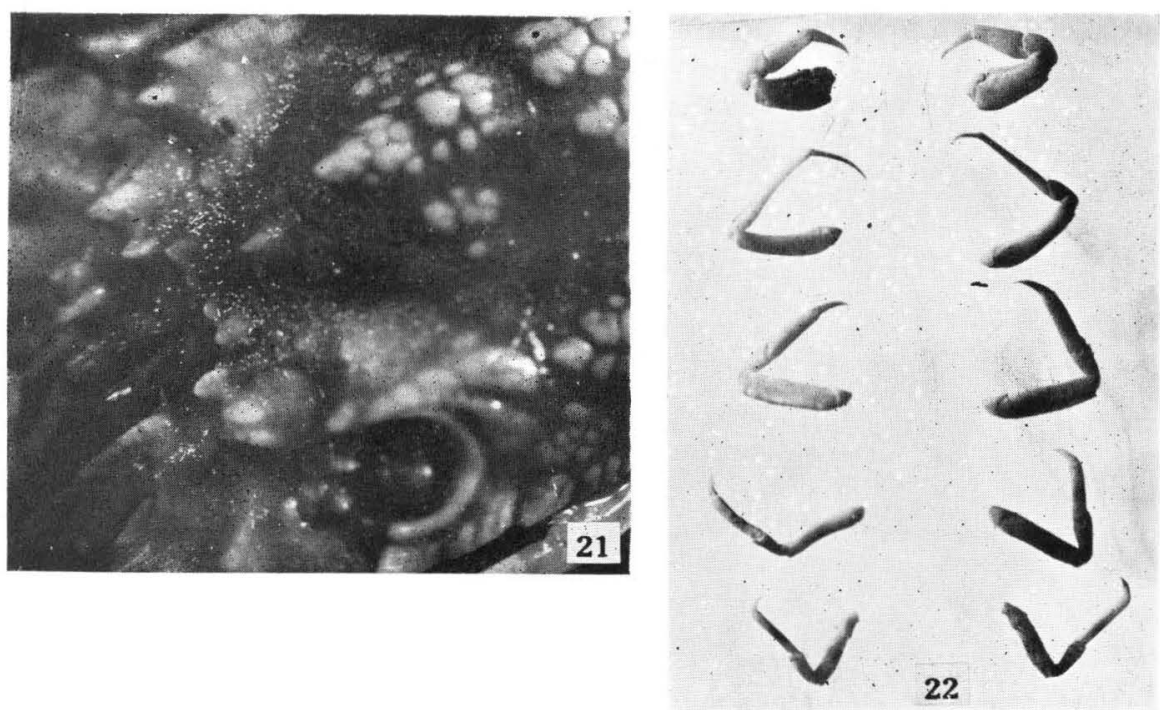

E. Harada: On the Genus Scyllarus from Japan.
PLATE XIV 